\title{
Perilaku Kesehatan Reproduksi Pasangan Usia Subur (PUS) Pada Komunitas Samin Di Kabupaten Blora
}

\author{
Sugiharta Jarot ${ }^{1}$, Suhardono ${ }^{2 *}$, Prasetyo Agus ${ }^{3}$ \\ 1,2,3 Prodi D-III Keperawatan Blora, Poltekkes Kemenkes Semarang, Indonesia
}

\author{
*Corresponding author : Suhardono \\ Email: spsuhardono@gmail.com
}

Received: March 11, 2020; Accepted: March 20, 2020, Published : March 31, 2020

\begin{abstract}
Background : Reproductive health problems in the community Samin especially couples of childbearing age is still a concern, they generally do not utilize reproductive health care facilities, have not followed the family planning program, do not follow government rules on health care, they are more trusting bewitched by the teachings Saminisme background.

Objective : The aim of this study was to describe reproductive health behavior on fertile age couple (PUS) Samin Communities In The District of Blora.

Methods : This research is descriptive quantitative and qualitative approaches, the draft through Exploration Research (explanatory research) The research sample comprised a total population of couples of reproductive age (PUS) Samin community in Blora, as many as 130 people. Sample Qualitative 12 people consisting of family (EFA) and 6 community leaders, and 6 health workers who are in the Samin community.The collection of quantitative data with structured interviews, and in-depth interviews for the qualitative data.The quantitative data in the descriptive analysis, while qualitative data analysis with deskrepsi contents.

Result : The results showed that $98.5 \%$ of respondents are knowledgeable both about the ante natal care, $96.2 \%$ of respondents are knowledgeable both about post natal care, $92.3 \%$ of respondents good knowledge about family planning. $97.7 \%$ of respondents are supportive of the ante natal care, $97.7 \%$ of respondents are supportive of the post natal care services, $97.7 \%$ of respondents are supportive of the KB and the ante natal care $95.4 \%$ of respondents, $92.3 \%$ of respondents do post-natal care , $76.2 \%$ of respondents planning. Variable knowledge has a very close relationship with a significance value of 0.003 to the magnitude of the possible influence of Odds Ratio (OR) was 14.881 (Exp (B), variable age with a significance value of 0.027 to the magnitude of the possible influence of Odds Ratio (OR) was 10.601 (Exp(B).

Conclusion : reproductive health knowledge Samin community largely understand the importance of reproductive health, especially in pregnancy, labor and birth, and yet people still believe Samin once with myths about reproductive health, and so maintain Saminisme cultural customs. For Blora District Health Office, the results of this study can be used as inputs in delivering the program - the EFA program, while for health centers in the region Samin can be input in the improvement of reproductive health care.
\end{abstract}

Keywords: Behavior, Reproductive Health, EFA, Samin

\section{Pendahuluan}

Permasalahan kesehatan reproduksi bukan hanya sekedar masalah kesehatan semata, melainkan merupakan bagian dari keseluruhan kehidupan manusia. Pelayanan kesehatan reproduksi diperlukan untuk memenuhi kebutuhan kesehatan perempuan dan laki-laki berhubungan dengan masalah seksualitas dan penjarangan kehamilan .

Setiap menit seorang ibu meninggal karena penyebab kehamilan dan persalinan. Ia biasanya berusia muda, sudah menjadi ibu dan hidup di negara ber-kembang. Dari setiap ibu meninggal tersebut, diperkirakan ada 100 wanita selamat saat bersalin tetapi mengalami kesakitan, cacat atau kelainan fisik akibat komplikasi kehamilan. Secara keseluruhan diperkirakan bahwa setiap tahunnya 585.000 wanita meninggal akibat kehamilan dan persalinan; 99 persen dari kematian tersebut terjadi di negara berkembang.

Angka kematian ibu tinggi merupakan salah satu indikasi dari lemahnya perlindungan terhadap hak-hak reproduksi perempuan.Tingginya angka 
kematian ibu melahirkan disebabkan antara lain kurangnya tenaga kesehatan terlatih di desa-desa yang murah dan mudah di akses oleh perempuan miskin, budaya masyarakat yang mengatakan banyak anak banyak rejeki, kurangnya pengetahuan masyarakat tentang kehamilan dan persalinan yang tepat, tidak tercukupinya gizi ibu hamil dan melahirkan dan rendahnya kebersihan lingkungan karena tidak tersedianya air bersih dan sanitasi yang memadai.

Tingginya angka kematian ibu ini tidak terlapas dari masih tingginya angka kehamilan yang tidak diinginkan yaitu mencapai 16,8 \% yang berkaitan dengan tingginya aborsi. Aborsi itu sendiri memberikan sumbangan terhadap kematian ibu sampai $13 \%$. Disisi lain masih banyak banyak ditemukan kehamilan yang tidak ideal (terlalu banyak, terlalu muda, terlalu tua, dan terlalu dekat jarak kehamilan), yang sangat membahayakan bagi kesehatan ibu atau lebih dikenal dengan 4 T. (3)

Angka kematian ibu Provinsi Jawa Tengah tahun 2014 berdasarkan laporan dari kabupaten/kota sebesar 126,55/100.000 kelahiran hidup, mengalami peningkatan bila dibandingkan dengan AKI pada tahun 2013 sebesar 118,62/100.000 kelahiran hidup, hal ini berarti terjadi peningkatan permasalahan kematian ibu di Provinsi Jawa Tengah.

Menurut hasil Laporan dari Dinas Kesehatan Kabupaten Blora Angka Kematian Ibu (AKI) di Kab. Blora tahun 2015 yang dilaporkan sebanyak 15 kasus kematian ibu dan 169 kasus kematian bayi.

Menurut data laporan dari DPPKKI (Dinas Perhubungan Pariwisata Kebudayaan Komunikasi dan Informatika) Kabupaten Blora, jumlah komunitas Samin Kabupaten Blora pada tahun 2016 sejumlah $649 \mathrm{KK}$ yang terdiri dari 1.122 jiwa yang bertempat tinggal tersebar 16 Kecamatan di Kabupaten Blora .

Adapun jumlah komunitas Samin yang tergolong pasangan usia subur (PUS) di Kabupaten Blora 130 pasangan usia subur.

Dari hasil studi pendahuluan yang dilakukan oleh peneliti dengan cara pengamatan langsung dan wawancara dengan masyarakat Samin, tokoh masyarakat Samin dan petugas kesehatan yang berada di 6 wilayah kecamatan Kabupaten Blora berkaitan dengan permasalahan kesehatan reproduksi komunitas Samin didapatkan informasi sebagai berikut : Komunitas Samin khususnya pasangan usia subur (PUS) belum secara optimal memanfaatkan sarana pelayanan kesehatan reproduksi di wilayah pelayanan terdekat. Berkaitan dengan banyak anak atau tidak mereka menganggap bahwa semua itu adalah kehendak dari Yang Kuasa. Budaya perkawinan ala Samin yang tidak menganut aturanyang diberlakukan dari pemerintah yaitu tercatat di Kantor Urusan Agama (KUA) atau di kantor Catatan Sipil, tetapi masih mengikuti tatacara adat kebudayaan yang diberlakukan pada komunitas samin (kumpul kebo / ngrukonke) ngenger).

Selain itu masih kuatnya mitos-mitos negatif tentang kesehatan reproduksi, misalnya budaya banyak anak banyak rejeki, membicarakan masalah kesehatan reproduksi sangat tabu dan itu merupakan urusan wanita, lahir, mati , jodoh itu semua kehendak Yang Kuasa, dan dalam pelayanan kesehatan reproduksi khususnya masalah pemeriksaan kehamilan, persalinan dan perawatan post partum masih dipercayakan pada dukun beranak, dan apabila dalam proses persalinan mengalami kesulitan baru memanggil atau datang ke tempat petugas kesehatan. Masih kurangnya informasi dalam bidang kesehatan kesehatan dan khususnya berkaitan dengan kesehatan reproduksi, dalam hal ini disebabkan karena budaya malu / tabu yang masih kuat, kesempatan waktu mendapat informasi sangat sedikit karena budaya kerja keras di sawah dilakukan dari pagi sampai sore hari di kalangan komunitas Samin. Masih kuatnya ajaran Saminisme yang diajarkan secara turun temurun, oleh sesepuh komunitas Samin atau orang tua dengan cara wulang reh.

Penelitian ini bertujuan untuk mendiskripsikan perilaku pasangan usia subur (PUS) pada komunitas Samin dalam kesehatan reproduksi di kabupaten Blora.

\section{Metode Penelitian}

Kerangka konsep penelitian ini mencakup variabel bebas dan variabel terikat. Variabel bebas terdiri dari 1) Karakteristik Pasangan usia subur (PUS); umur, pendidikan, pekerjaan, jumlah anak, 2) Pengetahuan PUS tentang kesehatan reproduksi, 3) Sikap PUS terhadap kesehatan reproduksi 4) Peranan petugas kesehatan dalam kesehatan reproduksi.

Adapun variabel terikat praktik PUS dalam kesehatan reproduksi (praktik Ante Natal Care, Post Natal Care dan Implementasi KB).

Penelitian ini merupakan penelitian deskriptif dengan pendekatan kuantitatif dan kualitatif. Rancangan penelitian yang digunakan dalam penelitian ini adalah Exploration Rescarch (penelitian penjelasan). Metode yang digunakan untuk kwantitaif tehnik pertanyaan kuesioner dan untuk kwalitatif menggunakan indeep interview dengan pertanyaan tematik terstruktur. Pendekatan kualitatif digunakan untuk Cross check secara kualitatif kapada keluarga PUS dan petugas 
kesehatan tentang praktik kesehatan reproduksi dikomunitas Samin.

Populasi dalam penelitian ini adalah pasangan usia subur (PUS) komunitas Samin di Kabupaten Blora, sebanyak 130 Orang, sample kuantitatif total populasi PUS komunitas Samin di Kabupaten Blora, sebanyak 130 Orang. Sample untuk penelitian kualitatif dengan perhitungan $10 \%$ dari sample kuantitatif. Adapun perhitunganya adalah $10 \% \mathrm{x}$ 130 = 12 sample keluarga, adapun responden adalah ibu dari PUS, 6 orang tokoh dalam komunitas Samin, dan 6 petugas kesehatan (bidan) yang bertugas di wilayah komunitas Samin di 6 Kecamatan Kabupaten Blora.

Alat yang digunakan adalah Kuisioner. Uji coba instrumen dilakukan pada responden yang mirip dengan subyek penelitian yaitu Pus Komunitas Samin diwilayah Desa Klopo Duwur Kec Blora Kota sebanyak 30 responden. Uji Validitas dilakukan terhadap total scor seluruh pertanyaan dengan menggunakan uji Person Product Moment dengan signifikan $5 \%$ nilai $r$ hitung $=0,306$. Uji Realibilitas Realibilitas alat ukur sangat berkaitan dengan error of measurement. Nilai pengukuran $5 \%$ dengan Alpha $\alpha 0,600$.

\section{Hasil dan Pembahasan}

\section{Karakteritik Responden}

Persentase kelompok umur terbesar adalah kelompok umur 20 - 29 tahun sebesar $51.3 \%$ sedangkan terkecil pada kelompok umur 15 - 20 tahun sebesar 8,8 \%. Gambaran tingkat pendidikan pasangan usia subur (PUS) komunitas Samin sebagian besar tamat SD sebanyak 61,3\% sedangkan persentase terkecil tingkat pendidikan SMA sebanyak 3,8 \% , dan jenis pekerjaan pasangan usia subur (PUS) komunitas Samin sebagian besar tani dan persentase terkecil adalah buruh 3,00\%, sedangkan gambaran Jumlah anak yang pernah dilahirkan oleh wanita usia subur sebagian besar melahirkan 1-2 anak dengan jumlah 66,3 \% dan persentase yang mempunyai anak lebih dari 3 sebesar 17,5 \%. Artinya masyarakat samin sudah memperhatikan jumlah anak sesuai dengan anjuran kesehatan.
Tabel 1. Distribusi Frekuensi Karakteritik Responden

\begin{tabular}{llcc}
\hline Karakteristik & \multicolumn{1}{c}{ Katagori } & f & $\%$ \\
\hline Kelompok & $15-20$ tahun & 11 & 8,8 \\
umur & $21-30$ tahun & 67 & 51,3 \\
& $31-40$ tahun & 52 & 40,0 \\
& $>40$ tahun & & \\
Pendidikan & Tidak sekolah & 11 & 8,8 \\
& 6 tahun & 80 & 61,3 \\
& 9 tahun & 21 & 16,3 \\
& 12 tahun & 13 & 10,0 \\
& 15 tahun & 5 & 3,8 \\
Pekerjaan & Tani & 80 & 61,3 \\
& Tidak bekera & 45 & 35,0 \\
& Buruh & 5 & 3,00 \\
Jumlah anak & Belum punya & 21 & 16,3 \\
& anak & 86 & 66,3 \\
& $1-2$ anak & 23 & 17,5 \\
& $3-5$ anak & & \\
\hline
\end{tabular}

2. Pengetahuan Responden Tentang Kesehatan Reproduksi

\section{a. Ante natal care}

Pengetahuan responden tentang usia ibu yang aman untuk hamil sebagian besar menyatakan umur 20 - 30 tahun sejumlah 100 $\%$ dan yang menyatakan usia ibu yang aman untuk hamil umur 15 - 19 tahun $0 \%$, dan pengetahuan responden tentang jumlah anak yang aman untuk dilahirkan untuk seorang ibu sebagian besar menyatakan 1 - 2 anak sebesar $92,3 \%$ dan yang menyatakan lebih dari 2 anak ada $7,7 \%$.

Pengetahuan reponden tentang jarak kehamilan yang aman untuk seorang ibu sebagian besar menyatakan baik sebanyak 60,8 $\%$. Artinya bahwa pasangan usia subur (PUS) di masyarakat Samin sudah mengetahui bahwa jarak kehamilan yang baik diatas 5 tahun. Pengetahuan mereka tentang jarak kehamilan karena memang budaya masyarakat Samin yang sudah punya cara tersendiri untuk mengatur jarak kehamilan, sehingga banyak pasangan usia subur (PUS) dengan jarak kehamilan diatas 5 tahun.

Pengetahuan responden tentang perawatan kehamilan (ante natal care) sebagian besar berpengetahuan baik ( 98,5 \%). Pengetahuan masyarakat Samin terhadap perawatan ante natal care sudah baik. 
Tabel 2. Distribusi frekuensi pengetahuan responden tentang A N C.

\begin{tabular}{|c|c|c|c|}
\hline Pengetahuan & Katagori & $f$ & $\%$ \\
\hline Umur aman & 1. $15-20$ th & 0 & 0 \\
\hline untuk hamil & $\begin{array}{l}\text { 2. } 21-30 \text { th } \\
\text { 3. } 31-45 \text { th }\end{array}$ & 130 & 100 \\
\hline Jumlah anak & 1. Aman (1- & 120 & 92,3 \\
\hline $\begin{array}{l}\text { yang aman } \\
\text { untuk } \\
\text { dilahirkan }\end{array}$ & $\begin{array}{c}\text { 2anak }) \\
\text { 2.Tidak Aman } \\
(>2 \text { anak })\end{array}$ & 10 & 7,7 \\
\hline Jarak & 1. Kurang & 51 & 39,2 \\
\hline $\begin{array}{l}\text { kehamilan } \\
\text { yang aman }\end{array}$ & 2. Baik & 79 & 60,8 \\
\hline Perawatan & 3. Kurang & 2 & 1,5 \\
\hline kehamilan & 4. Baik & 128 & 98,5 \\
\hline
\end{tabular}

- "Biasane yen bobot sepisanan niku di brokohi kersane sing bobot ugi bayine slamet " (Biasanya kalau hamil pertama kali dilakukan selamatan agar ibu yang hamil dan bayinya selamat)

- "Kawitane entene tiyang istri niku mbobot, niku wong wedok pangaran si A niku sampun demen kalih tiyang lanang pangaran si A niku sampun demen, sing wedok sampun seneng inggih niku entene kawitane tiyang ngandheg." (Awal dari adanya orang hamil, anak perempuan nama si A sudah cinta dengan anak laki-laki dengan nama si A sudah saling mencintai, ya itu adanya orang hamil)

- "Babagan bobot niku biasa pak, mboten ngurangi nopo-nopo, nyambut damel inggih biasa mboten ngurangi " (Masalah hamil itu biasa pak, tidak mengurangi apa-apa, bekerja juga tidak dikurangi). Tokoh masyarakat, 65 tahun.

Menurut adat masyarakat Samin bahwa kehamilan terjadi karena adanya pernikahan secara adat " sikep Rabi “. Merupakan hal yang biasa terjadi pada seorang wanita jika sudah 'Sikep Rabi “ mengalami kehamilan. Kemudian jika wanita sedang hamil menurut adat Samin tidak perlu untuk mengurangi kegiatan apapun. Sehingga tetap melakukan aktifitas sehari-hari seperti biasanya pada saat sebelum hamil.

Dengan demikian bahwa wanita masyarakat Samin tidak boleh menerima pengetahuan yang lebih selain urusan dapur.

\section{$b$. Tingkat pengetahuan responden tentang Post Natal Care}

Pengetahuan tentang perawatan persalinan (post natal care ) sebagian besar responden berpengetahuan baik ( 96,2 \%) ). Pengetahuan tentang perawatan pasangan usia subur (PUS) setelah melahirkan baik, tetapi sebagian kecil masih kurang mereka menganggap bahwa jika tidak ada kelainan tidak perlu pergi ke petugas kesehatan, cukup dengan dukun beranak/ bayi.

Tabel 3. Distribusi Frekuensi pengetahuan responden tentang post natal care.

\begin{tabular}{ccc}
\hline \multicolumn{1}{c}{ Post natal care } & Frekuensi & $\%$ \\
\hline Kurang Baik $(<75 \%)$ & 5 & 3,8 \\
Baik ( > 75 \% ) & 125 & 96,2 \\
\hline \multicolumn{2}{c}{ "Menawi ajeng nglairke sing nulung sakniki }
\end{tabular}

inggih ibu Bidan niku namine kerukunan, sak sampun ipun ditulung ibu bidan sing rawat ibune kalih bayine gantos mbah dukun ngantos selapan"

"Inggih niku bayine yen turu di tunggu kalih lading, ibune bayi yen kesah inggih mbeto lading kersane mboten diganggu kalih sing mboten ketingal."

"Bubar nglairike' ibune mboten pikantuk mandap saking dipan tur mboten pikantuk medal griyo ngantos sepasar mundak kinging sawan "

"Wayah surup bayi ora keno metu-metu soko omah mundak keno sawan " Ibu Rn, 46 tahun.

Pernyataan diatas bahwa apabila mau melahirkan sekarang ditolong oleh Bidan dan setelah lahir ibu dan bayinya dirawat oleh Dukun beranak sampai usia bayi 40 hari. Mitos-mitos yang dipercayai pada persalinan jika bayi sudah lahir, ditempat tidurnya diletakkan senjata yang disebut "lading" dan ibunya jika bepergian juga harus membawa "lading" dan bayi setelah menjelang malam tidak boleh keluar rumah menurut kepercayaan mereka supaya tidak diganggu oleh mahluk gaib. Setelah melahirkan ibu tidak boleh turun dari tempat tidur dan keluar rumah sampai 5 hari dikawatirkan terkena gangguan mahluk gaib.

" Perkoro ngrumat ari-ari dipasrahke mbah dukun : yen sing lahir turunan lanang ari-ari diwadahi kendil soko lemah, disunggi lan dipendem sisih tengen pintu ngarep omah dipendem luwih jero tujuane' bayi besok gede iso mendem jero mikul duwur wong tuane'. Yen sing lahir bayi wadon dipendem sisih kiwo pintu ngarep omah, dipendem luwih cethek tujuane' ben cethek jodone "

"Yen ngedusi bayi wadah banyu kudu sing digawe ngango soko lemah nganti selapan ngemu ateges wong asale soko lemah besok mbalik dadi lemah. Sak wise selapan iso nganggo wadah banyu liyane "

Ibu Jt, 30 tahun.

Menurut keterangan diatas dalam merawat ari-ari (Plasenta) deserahkan oloh dukun bayi, apabila bayi yang lahir laki-laki ari-ari ditempatkan sebuah wadah yang terbuat dari tanah (tempayan) ditanam lebih dalam disebelah kanan pintu depan rumah mengandung maksud supaya bayi yang dilahirkan bisa mensejahterakan orang tuanya. Sedangkan apabila bayi yang lahir perempuan ariari ditempatkan sebuah wadah yang terbuat dari tanah (tempayan) ditanam lebih rendah disebelah kiri pintu depan rumah mengandung maksud supaya 
bayi yang dilahirkan bisa mendapat jodeh lebih cepat.

Dalam memandikan bayi harus memakai wadah air terbuat dari tanah sampai bayi berumur 40 hari mempunyai tujuan memberikan pembelajaran bahwa manusia berasal dari tanah akan kembali menjadi tanah kembali.

\section{c. Tingkat Pengetahuan Tentang KB}

Pengetahuan tentang keluarga berencana ( $\mathrm{K}$ B ) sebagian besar responden berpengetahuan baik ( 92,3 \% ). pasangan usia subur (PUS) dimasyarakat Samin masih terdapat salah persepsi tentang program KB sebanyak 7,7 \% , dikerenakan menurut masyarakat Samin semenjak mereka menikah mereka sudah ber KB. Adapun untuk menggunakan alat-alat atau sarana yang harus digunakan tidak lazim di gunakan dimasyarakat Samin. Akan tetapi mereka mempunyai cara sendiri untuk menjarangkan kehamilan. Jika mereka menggunakan alat kontrasepsi hanya sekedar mengikuti anjuran tenaga kesehatan atau mengikuti teman-teman, bukan kesadaran sendiri.

Tabel 4. Distribusi Frekuensi pengetahuan responden tentang $K B$

\begin{tabular}{ccc}
\hline $\begin{array}{c}\text { Keluarga Berencana } \\
\text { (KB) }\end{array}$ & $\begin{array}{c}\text { Frekuensi } \\
\text { (f) }\end{array}$ & $\%$ \\
\hline Kurang Baik $(<75 \%)$ & 10 & 7,7 \\
Baik $(>75 \%)$ & 120 & 92,3 \\
\hline
\end{tabular}

“ Tiyang mriki sedoyo inggih sampun nderek $K B$ angger sampun sikep rabi niku inggih sampun $K B$, yen KB wonten bidan niku kerukunan."

Bp. Tb 35 Th

Van Baal (1987 : 60) mengatakan bahwa kekerabatan aslinya termasuk dalam konteks hubungan yang lestari antara suami isteri, yang secara sosial diakui dengan ciri-ciri a) pergaulan kelamin yang berkelanjutan; b) hidup bersama dan bekerja sama ekonomi; c) pemeliharaan anak-anak yang dilahirkan oleh isteri karena hubungan yang berlangsung itu. Hubungan semacam itu adalah perkawinan, dan kelompok yang terbentuk sebagai akibat perkawinan adalah rumah tangga (nuclear family).

Dengan demikian karena budayanya sudah menetapkan seperti itu, maka keluarga berencana menurut masyarakat samin sesuatu yang meniru orang lain dan bukan merupakan budayanya, sehingga mereka mengatakan "kerukunan" atau dalam arti "ikut-ikutan".

\section{Sikap Responden Terhadap Kesehatan Reproduksi}

a. Sikap Responden terhadap Ante Natal Care

Sebagaian besar sikap responden terhadap pelayanan kesehatan yang menerima terhadap ante natal care sebanyak $97,7 \%$ dan yang tidak menerima terhadap pelayanan kesehatan sebanyak
2,3 \%. Artinya bahwa sebenarnya masyarakat Samin menerima pengetahuan baru yang ada, akan tetapi untuk pelaksanaanya masih sangat dipengaruhi oleh budaya yang ada. Kehamilan menurut mereka adalah hal yang wajar dan mereka menerima bahwa kondisinya harus dijaga akan tetapi selama kehamilannya tidak ada kelaianan yang tidak perlu datang ke petugas kesehatan.

Tabel 5 Distribusi frekuensi sikap responden terhadap Ante Natal Care

\begin{tabular}{lcc}
\hline Sikap Terhadap & Frekuensi (f) & $\%$ \\
Ante Natal Care & & \\
\hline Tidak Mendukung & 3 & 2,3 \\
Mendukung & 127 & 97,7 \\
\hline \multicolumn{1}{c}{ Inggih pripun sami kalian tiyang } & kathah
\end{tabular}

kersane sae mengke diopeni sing sae wong tujuane inggih sae. " (Ya semestinya sama dengan orang banyak, agar baik nanti dipelihara yang baik karena tujuannya juga baik)

\section{b. Sikap responden terhadap Post natal care}

Sikap responden terhadap pelayanan kesehatan yang menerima terhadap post natal care sebanyak $97,7 \%$ dan yang tidak menerima terhadap pelayanan kesehatan sebanyak 2,3\%.

Tabel 6. Distribusi frekuensi sikap responden terhadap Post Natal Care

\begin{tabular}{lcc}
\hline $\begin{array}{l}\text { Sikap Terhadap Post } \\
\text { Natal Care }\end{array}$ & Frekuensi (f) & $\%$ \\
\hline Tidak Mendukung & 3 & 2,3 \\
Mendukung & 127 & 97,7 \\
\hline
\end{tabular}

" Carene ngrawat kehamilan sampun derek anjuran pemerintah prikso wonten Bidan utawi Puskesmas

" Ibu ngandek mboten pikantuk lungguh wonten tengah lawang kersane yen nglahirke' mboten anggel "

"Ibu ngendek yen madhang mboten angsal disonggo ngemu ateges yen nglahirke ora kabotan "

"Ibu sing ngandek ora keno mangan endog wutuhan mundak yen nglarani ngaleh-ngaleh "

" Ibu sing ngandeg ora keno madhang karo turon tujuane' supoyo anake' ora dadi bocah bodho "

"Nalikane ngandek umur 6 wulan sing jaler poso senin kemis supoyo wiji sing sejati dadi bocah bener lan pinter biso munggah drajat lan pangkat lan biso mikul duwur mendem jero "Tokoh komunitas Samin $65 \mathrm{Th}$

Untuk merawat kehamilan sudah mengikuti anjuran pemerintah ibu hamil sudah memeriksakan kehamilannya di Bidan dan atau di Puskesmas. Ibu hamil tidak boleh duduk ditengah pintu upaya saat melahirkan tidak mengalami kesulitan, dan apabila makan piring tidak boleh disangga mengandung maksud bila melahirkan biar tidak terasa berat. Selain itu saat makan tidak boleh posisi tiduran mengandung maksud bayi yang dilahirkan kalau sudah dewasa tidak menjadi orang yang bodoh. 
Saat hamil ibu dilarang makan telur dalam keadaan wutuh mempunyai tujuan bila saat kesakitan menjelang melahirkan tidak berpindah pindah tempat. Saat kehamilan mencapai umur kehamilan 6 bulan sang ayah puasa Senin - Kamis supaya bibit yang sejati jadi anak yang benar dan pintar bisa naik drajad dan pangkatnya dan bisa berbakti pada orang tua.

\section{c. Sikap responden terhadap Keluarga Berencana (KB)}

Sikap responden terhadap pelayanan KB yang menerima sebanyak $97,7 \%$ dan yang tidak menerima terhadap pelayanan KB sebanyak 2,3\%. Sikap menerima terhadap keluarga berencana sangat baik, akan tetapi mereka jarang yang menggunakan sarana KB. Mereka menggunakan dengan caranya sendiri.

Tabel 7. Distribusi frekuensi sikap responden terhadap KB

\begin{tabular}{cccc}
\hline No & $\begin{array}{c}\text { Sikap } \\
\text { Terhadap KB }\end{array}$ & $\begin{array}{c}\text { Frekuensi } \\
\text { (f) }\end{array}$ & $\%$ \\
\hline 1 & Tidak & 3 & 2,3 \\
2 & Mendukung & 127 & 97,7
\end{tabular}

"Ya dia juga ada yang mengikuti KB, mengikuti KB itu semata mata karena dia mengikuti umumnya orang lain. Jadi dia itu ber KB karena dia mengikuti apa yang dilakukan orang lain tidak murni dari niat sendiri."

" Kebanyakan KB yang dipakai oleh masyarakat samin adalah suntik. dan dia mungkin pakai cara tradisional, kata lain dia mengungkapkan KB mandiri dan pakai ramuan-ramuan." Bidan Ds $34 \mathrm{Th}$.

\section{Praktek Responden Dalam Kesehatan Reproduksi}

a. Praktek Responden dalam Ante Natal Care

Sebagaian besar responden melakukan ante natal care sebanyak 95,4 \% dan yang tidak melakukan hanya 4,6 \%. Praktek ante natal care untuk memeriksakan kehamilan pada pelayanan kesehatan adalah hal yang belum disadari oleh pasangan usia subur ( PUS) masyarakat Samin, karena menurut mereka kehamilan adalah hal yang biasa terjadi pada wanita yang sudah menikah. Sehingga dia menyadari bahaya-bahaya yang mungkin terjadi jika tidak melakukan pemeriksaan kehamilan.

Tabel 8 . Distribusi frekuensi praktek responden Ante Natal Care

\begin{tabular}{lcc}
\hline $\begin{array}{c}\text { Praktek Ante Natal } \\
\text { Care }\end{array}$ & $\begin{array}{c}\text { Frekuensi } \\
\text { (f) }\end{array}$ & $\%$ \\
\hline Tidak melakukan & 6 & 4,6 \\
Melakukan & 124 & 95,4
\end{tabular}

\footnotetext{
"Tiyang mriki yen ngandeg biasane nggih didulegke wonten mbah dukun."

(Orang sini kalau hamil biasanya ya dipijatkan di tempat mbah dukun). Ibu Nt, 36 tahun.
}

"Kadang-kadang kalau dia sudah datang ke tenaga kesehatan dan sudah mendapatkan nasehat dari petugas kesehatan diapun juga mau memeriksakan kehamilannya secara rutin. Periksa rutin itu berdasarkan dari nasehat petugas kesehatan bukan niat sendiri. "“ Pada umumnya mereka masih memeriksakan kehamilannya di dukun, baru setelah menginjak usia kehamilan 7 bulan mereka datang ke Bidan. Namun ada juga yang mulai usia kehamilan muda mereka memeriksakan kehamilannya ke Bidan" Bidan Li 40 Th

Sikap belum dapat dilihat secara nyata, artinya sikap itu masih dalam diri seseorang sehingga kita sulit untuk mengetahui bagaimana sikap seseorang terhadap sesuatu. Newcomb, salah seorang ahil psikologi social yang dikutip Notoatmodjo (1993) menyatakan bahwa sikap itu merupakan pelaksana motif tertentu. Sikap itu masih merupakan reaksi tertutup, bukan merupakan reaksi terbuka atau tingkah laku yang terbuka. Sikap masyarakat Samin sangat mengerti program-program kesehatan yang ada, akan tetapi tidak harus menjalani. Sikap pasrah kepada yang Maha Kuasa masih sangat kuat .

\section{b. Praktek Responden dalam Post Natal Care}

Sebagian besar responden melakukan perawatan pasca persalinan ( post natal care ) sebanyak 92,3\% dan yang tidak melakukan hanya 7,7\%. Sama seperti pada perawatan kehamilan, bahwa perawatan persalinan yang dilakukan oleh PUS masysrakat Samin adalah hanya melakukan selamatan, akan tetapi yang harus dikontrol secara kesehatan mereka tidak memperhatikan, pada saat ada kelainan saja baru menggunakan pelayanan kesehatan.

Tabel 9. Distribusi frekuensi praktek responden post natal care

\begin{tabular}{lcc}
\hline $\begin{array}{c}\text { Praktek Post Natal } \\
\text { Care }\end{array}$ & $\begin{array}{c}\text { Frekuensi } \\
(f)\end{array}$ & $\%$ \\
\hline Tidak melakukan & 10 & 7,7 \\
Melakukan & 120 & 92,3 \\
\hline
\end{tabular}

"Pada intinya masyarakat samin sudah bisa diatur untuk memeriksakan kehamilannya, untuk bersalin di tenaga kesehatan dan untuk kontrol sehabis melahirkan. Akan tetapi mereka masih percaya dengan mitos-mitos jawa seperti contohnya pada waktu hamil tidak boleh potong rambut, suami tidak boleh membunuh hewan,suami tidak boleh dandan/membangun rumah, dan lain-lain. Pada waktu bersalin bumil atau yang mendampingi rambut harus diurai, jendela, pintu lemari harus dibuka, menium kepala ibu bersalin agar cepat lahir, minta air dan lain-lain. Pada waktu post partum sebagian ada yang tidak boleh keluar sebelum selapan." Bidan Dw. 35 th 


\section{c. Praktek Responden dalam Keluarga \\ Berencana ( KB)}

Sebagian besar responden melakukan keluarga berencana (KB) sebesar 76,2 \% dan yang tidak melakukan hanya 23,8 \%. Pasangan usia subur (PUS) masyarakat Samin sangat mengerti dan menerima adanya pengaturan seperti keluarga berencana, akan tetapi mereka tidak menggunakan sarana keluarga berencana yang disediakan oleh layanan kesehatan dengan alasan bahwa mereka sudah punya cara sendiri untuk mengatur kehamilan. Menurut pengakuan mereka cara mereka ber $\mathrm{KB}$ ada banyak macam seperti dengan ramuan, atau tidak melakukan mengatur hubungan seksual.

Tabel .10. Distribusi frekuensi praktek responden dalam $K B$

\begin{tabular}{lcc}
\hline Praktek dalam KB & $\begin{array}{c}\text { Frekuensi } \\
\text { (f) }\end{array}$ & $\%$ \\
\hline Tidak melakukan & 31 & 23,8 \\
Melakukan & 99 & 76,2 \\
\hline
\end{tabular}

"Ya pada dasarnya masyarakat samin disini ya tanggapan juga baik terhadap pelayanan petugas kesehatan, karena diapun sadar kalau diapun membutuhkan pelayanan kesehatan terutama kalau dia mengalami sakit"

"Juga terbukti dengan adanya posyandu mereka juga mau membawa anaknya ke posyandu untuk ditimbang, diimunisasi meskipun kadang perlu dioyak-oyak dulu". Bidan, 38 tahun.

Menurut L.Green dalam mengidentifikasi masalah harus waspada terhadap masalah yang sebenarnya erat sekali menyebabkan munculnya masalah kesehatan tersebut, tetapi nampaknya hal ini bukan masalah perilaku. Yaitu faktor yang memperkuat (atau kadang-kadang justru dapat memperlunak) untuk terjadinya perilaku tertentu tersebut. Yang termasuk dalam kelompok faktor penguat ini adalah : Pendapat dukungan, kritik baik dari keluarga, teman-teman sekerja atau lingkungannya bahkan juga dari petugas kesehatan sendiri. Oleh karena itu diharapkan dengan adanya petugas kesehatan sedikit demi sedikit mampu mengenalkan akan kebutuhan terhadap hidup sehat untuk menurunkan angka kematian ibu.
4. Hubungan Antara Tingkat Pengetahuan Responden Dengan Sikap Responden Terhadap Kesehatan Reproduksi (Ante Natal Care).

Tabel .11. Distribusi frekuensi Hubungan Antara Tingkat Pengetahuan Responden Dengan Sikap Responden Terhadap Kesehatan Reproduksi (Ante Natal Care).

\begin{tabular}{|c|c|c|c|c|c|c|}
\hline \multirow{3}{*}{$\begin{array}{c}\text { Sikap } \\
\text { Responden } \\
\text { tentang } \\
\text { ANC } \\
\end{array}$} & \multicolumn{4}{|c|}{ Pengetahuan ANC } & \multirow{2}{*}{\multicolumn{2}{|c|}{ Total }} \\
\hline & \multicolumn{2}{|c|}{ Baik } & \multicolumn{2}{|c|}{ Kurang } & & \\
\hline & $\mathrm{N}$ & $\%$ & $\mathrm{~N}$ & $\%$ & $\mathrm{n}$ & $\%$ \\
\hline Baik & 51 & 60,7 & 33 & 39,3 & 84 & 100 \\
\hline Kurang & 19 & 41,3 & 27 & 58,7 & 46 & 100 \\
\hline \multicolumn{3}{|c|}{$\mathrm{X}^{2}: 4,506 \mathrm{p}$ value $=0.034$} & \multicolumn{3}{|c|}{ Ho=ditolak } & \\
\hline
\end{tabular}
komunitas Samin yang mempunyai pengetahuan baik dan mempunyai sikap baik sebesar 51 responden $(60,7 \%)$ dibandingkan dengan responden yang mempunyai pengetahuan kurang sebesar 33 responden (39,3\%). Dari hasil uji Chi Square dengan taraf signifikansi 0.05 diperoleh $\mathrm{p}$ value 0.034 ( $\mathrm{p}$ value $<0.05$ ) berarti Ho ditolak, yang berarti bahwa ada hubungan antara tingkat pengetahuan responden dengan sikap responden tentang kesehatan reproduksi ante natal care di Kabupaten Blora.

5. Hubungan Antara Tingkat Pengetahuan Responden Dengan Praktik Responden Terhadap Kesehatan Reproduksi (Ante Natal Care).

Tabel. 12. Distribusi frekuensi Hubungan Antara Tingkat Pengetahuan Responden .Dengan Praktik Responden Terhadap Kesehatan Reproduksi (Ante Natal Care).

\begin{tabular}{lccccccc}
\hline Praktik & \multicolumn{3}{c}{ Pengetahuan ANC } & \multirow{2}{*}{ Total } \\
\cline { 2 - 5 } $\begin{array}{l}\text { Responden } \\
\text { tentang }\end{array}$ & \multicolumn{2}{c}{ Baik } & \multicolumn{2}{c}{ Kurang } & & \\
\cline { 2 - 6 } ANC & $\mathrm{N}$ & $\%$ & $\mathrm{n}$ & $\%$ & $\mathrm{n}$ & $\%$ \\
\hline Baik & 45 & 45 & 55 & 55 & 100 & 100 \\
Kurang & 25 & 83,3 & 5 & 16,7 & 30 & 100 \\
\hline $\mathrm{X}^{2}: 10.991$ & $\mathrm{p}$ value $=0.000$ & & Ho=ditolak &
\end{tabular}

Responden pasangan usia subur komunitas Samin yang mempunyai pengetahuan baik tentang ante natal care dan mempunyai praktik tentang ante natal care baik sebesar 45 responden (45\%) dibandingkan dengan responden yang mempunyai pengetahuan kurang tentang ante natal care sebesar 25 responden (83,3\%). Dari hasil uji Chi Square dengan taraf signifikansi 0.05 diperoleh $\mathrm{p}$ value 0.000 ( $\mathrm{p}$ value < 0.05) berarti Ho ditolak, yang berarti bahwa ada hubungan antara tingkat pengetahuan responden dengan praktik responden 
terhadap kesehatan reproduksi ante natal care, $\mathrm{di}$ Kabupaten Blora.

\section{Hubungan Antara Tingkat Pengetahuan Responden Dengan Sikap Responden Terhadap Kesehatan Reproduksi (Post Natal Care).}

Tabel 13. Distribusi frekuensi Hubungan Antara Tingkat Pengetahuan Responden Dengan Sikap Responden Terhadap Kesehatan Reproduksi (Post Natal Care).

\begin{tabular}{ccccccc}
\hline Sikap & \multicolumn{3}{c}{ Pengetahuan PNC } & \multirow{2}{*}{ Total } \\
\cline { 2 - 5 } \begin{tabular}{c} 
Responden \\
tentang \\
\cline { 2 - 5 } PNC
\end{tabular} & $\mathrm{N}$ & $\%$ & $\mathrm{~N}$ & $\%$ & $\mathrm{~N}$ & $\%$ \\
\hline Baik & 62 & 60.8 & 40 & 39.2 & 102 & 100 \\
Kurang & 6 & 21.4 & 22 & 35.5 & 28 & 100 \\
\hline $\mathrm{X}^{2}=10.991$ & \multicolumn{4}{c}{$p$ value $=0.000$} & \multicolumn{1}{c}{ Ho $=$ ditolak } \\
\hline
\end{tabular}

Responden pasangan usia subur komunitas Samin yang mempunyai pengetahuan post natal care baik dan mempunyai praktik baik tentang PNC sebesar 62 responden $(60,8 \%)$ dibandingkan dengan responden yang mempunyai pengetahuan kurang tentang post natal care sebesar 6 responden $(21,4 \%)$. Dari hasil uji Chi Square dengan taraf signifikansi 0.05 diperoleh $\mathrm{p}$ value 0.000 ( $\mathrm{p}$ value 0.05 ) berarti Ho ditolak, yang berarti bahwa ada hubungan antara tingkat pengetahuan responden dengan sikap responden terhadap kesehatan reproduksi post natal care di Kabupaten Blora

7. Hubungan Antara Tingkat Pengetahuan

Responden Dengan Praktik Responden Terhadap Kesehatan Reproduksi (Post Natal Care).

Tabel 14. Distribusi frekuensi Hubungan Antara Tingkat Pengetahuan Responden .Dengan Praktik Responden Terhadap Kesehatan Reproduksi (Post Natal Care).

\begin{tabular}{ccccccc}
\hline Praktik & \multicolumn{3}{c}{ Pengetahuan PNC } & \multirow{2}{*}{ Total } \\
\cline { 2 - 5 } \begin{tabular}{c}
\multicolumn{2}{c}{ Responden } \\
tentang \\
\cline { 2 - 5 } PNC
\end{tabular} & $\mathrm{N}$ & $\%$ & $\mathrm{~N}$ & $\%$ & $\mathrm{~N}$ & $\%$ \\
\hline Baik & 43 & 70.5 & 18 & 29.5 & 61 & 100 \\
Kurang & 44 & 63.6 & 25 & 36.2 & 69 & 100 \\
\hline $\mathrm{X}^{2}=15.23$ & \multicolumn{3}{c}{$p$ value $=0.000$} & Ho $=$ & ditolak \\
\hline
\end{tabular}

Responden pasangan usia subur (komunitas Samin yang mempunyai pengetahuan post natal care baik dan mempunyai praktik baik tentang post natal care sebesar 43 responden (70,5\%) dibandingkan dengan responden yang mempunyai pengetahuan kurang sebesar 25 responden (36,2\%). Dari hasil uji Chi Square dengan taraf signifikansi 0.05 diperoleh $\mathrm{p}$ value 0.000 ( $\mathrm{p}$ value< 0.05 ) berarti Ho ditolak, yang berarti bahwa ada hubungan antara tingkat pengetahuan responden .dengan praktik responden terhadap kesehatan reproduksi perawatan post natal care di Kabupaten Blora.
8. Hubungan Antara Tingkat Pengetahuan Responden Tentang KB Dengan Sikap Responden Tentang KB

Tabel.15 Distribusi frekuensi Hubungan Antara Tingkat Pengetahuan Responden Tentang KB Dengan Sikap Responden Tentang KB

\begin{tabular}{|c|c|c|c|c|c|c|}
\hline \multirow{3}{*}{$\begin{array}{c}\text { Sikap } \\
\text { Responden } \\
\text { tentang KB }\end{array}$} & \multicolumn{4}{|c|}{ Pengetahuan KB } & \multirow{2}{*}{\multicolumn{2}{|c|}{ Total }} \\
\hline & \multicolumn{2}{|c|}{ Baik } & \multicolumn{2}{|c|}{ Kurang } & & \\
\hline & $\mathrm{N}$ & $\%$ & $\mathrm{~N}$ & $\%$ & $\mathrm{~N}$ & $\%$ \\
\hline Baik & 81 & 72.3 & 31 & 27.7 & 112 & 100 \\
\hline Kurang & 7 & 38.9 & 11 & 61.1 & 18 & 100 \\
\hline$X^{2}=15,2$ & \multicolumn{4}{|c|}{$p$ value $=0.00$} & dit & \\
\hline
\end{tabular}

Responden pasangan usia subur (PUS) komunitas Samin yang mempunyai pengetahuan tentang KB baik dan mempunyai praktik baik tentang KB sebesar 81 responden (72,3\%) dibandingkan dengan responden yang mempunyai pengetahuan kurang sebesar 7 responden $(38,9 \%)$. Dari hasil uji Chi Square dengan taraf signifikansi 0.05 diperoleh $\mathrm{p}$ value 0.005 ( $\mathrm{p}$ value $<0.05$ ) berarti Ho ditolak, yang berarti bahwa ada hubungan antara tingkat pengetahuan responden dengan praktik responden terhadap kesehatan reproduksi (Keluarga Berencana) di Kabupaten Blora.

\section{Hubungan Antara Tingkat Pengetahuan Responden Tentang KB Dengan Praktik Responden Tentang KB}

Tabel 16. Distribusi frekuensi Hubungan Antara Tingkat Pengetahuan Responden Tentang KB Dengan Praktik Responden Tentang KB.

\begin{tabular}{ccccccc}
\hline Praktik & \multicolumn{3}{c}{ Pengetahuan KB } & \multirow{2}{*}{ Total } \\
\cline { 2 - 5 } Responden & \multicolumn{2}{c}{ Baik } & \multicolumn{2}{c}{ Kurang } & \multicolumn{1}{c}{} \\
\cline { 2 - 6 } tentang KB & $\mathrm{N}$ & $\%$ & $\mathrm{~N}$ & $\%$ & $\mathrm{~N}$ & $\%$ \\
\hline Baik & 83 & 70.3 & 35 & 297 & 118 & 100 \\
Kurang & 5 & 41.7 & 7 & 58.3 & 18 & 100 \\
\hline $\mathrm{X}^{2}=15,23$ & \multicolumn{3}{c}{$p$ value $=0.043$} & Ho $=$ & ditolak
\end{tabular}

Responden pasangan usia subur (PUS) komunitas Samin yang mempunyai pengetahuan tentang KB baik dan mempunyai praktik baik tentang KB sebesar 83 responden $(70,3 \%)$ dibandingkan dengan responden yang mempunyai pengetahuan kurang sebesar 7 responden (58,9\%). Dari hasil uji Chi Square dengan taraf signifikansi 0.043diperoleh $\mathrm{p}$ value 0.005 ( $\mathrm{p}$ value $<0.05$ ) berarti Ho ditolak, yang berarti bahwa ada hubungan antara tingkat pengetahuan responden .dengan praktik responden terhadap kesehatan reproduksi Keluarga Berencana di Kabupaten Blora. 
10. Variabel Yang Paling Berhubungan Pada PUS Komunitas Samin Terhadap Kesehatan Reproduksi (Ante Natal Care, Post Natal Care, Implementasi KB) Di Kabupaten Blora

Tabel.17. Variabel yang paling berhubungan pada PUS komunitas samin terhadap kesehatan reproduksi (ante natal care, post natal care, implementasi KB) di Kabupaten Blora

\begin{tabular}{|c|c|c|c|c|c|c|c|c|}
\hline & \multirow[t]{2}{*}{ B } & \multirow[t]{2}{*}{ S.E. } & \multirow[t]{2}{*}{ Wald } & \multirow[t]{2}{*}{ Df } & \multirow[t]{2}{*}{ Sig. } & \multirow[t]{2}{*}{$\operatorname{Exp}(B)$} & \multicolumn{2}{|c|}{$\begin{array}{l}\text { 95.0\% C.I.for } \\
\text { EXP(B) }\end{array}$} \\
\hline & & & & & & & Lower & Upper \\
\hline Penganc(1) & 1.624 & .549 & 8.741 & 1 & .003 & 5.072 & 1.729 & $\begin{array}{r}14.88 \\
1\end{array}$ \\
\hline Usia & & & 6.827 & 2 & .033 & & & \\
\hline Usia(2) & 1.250 & .567 & 4.862 & 1 & .027 & 3.490 & 1.149 & $\begin{array}{r}10.60 \\
1\end{array}$ \\
\hline $\begin{array}{l}\text { Skpanc(1) } \\
\text { Constant }\end{array}$ & $\begin{array}{r}-.799 \\
-2.995\end{array}$ & $\begin{array}{l}.541 \\
.652\end{array}$ & $\begin{array}{r}2.179 \\
21.086\end{array}$ & $\begin{array}{l}1 \\
1\end{array}$ & $\begin{array}{l}.140 \\
.000\end{array}$ & $\begin{array}{l}.450 \\
.050\end{array}$ & .156 & 1.299 \\
\hline
\end{tabular}

Berdasarkan pada table 17 menunjukkan bahwa dari 3 veriabel bebas yang berhubungan secara signifikan dengan variabel terikat, ada 1 variable yang berpengaruh yaitu variable pengetahuan dengan nilai signifikansi 0,003 dengan besarnya kemungkinan pengaruh Odds Ratio (OR) adalah 14,881 (nilai $\operatorname{Exp(B),~variable~umur~dengan~nilai~signifikansi~0,027~dengan~besarnya~kemungkinan~pengaruh~Odds~}$ Ratio (OR) adalah 10,601 (nilai $\operatorname{Exp(B).~Hal~ini~berarti~bahwa~responden~dengan~pengetahuan~yang~baik~}$ mempunyai kemungkinan 14,881 kali lebih besar pengaruhnya untuk kesehatan reproduksi (ante natal care, post natal care , implementasi KB) pada pasangan usia subur (PUS) komunitas Samin di Kabupaten Blora dan umur responden mempunyai kemungkinan 10,601 kali lebih besar pengaruhnya untuk kesehatan reproduksi (ante natal care, post natal care, implementasi $\mathrm{KB}$ ) pada pasangan usia subur (PUS) komunitas Samin di Kabupaten Blora

\section{Kesimpulan}

1. Kelompok umur pasangan usia subur (PUS) terbesar adalah kelompok umur 20-30 tahun sebesar $51.3 \%$. Tingkat pendidikan pasangan usia subur (PUS) komunitas Samin Kabupaten Blora tahun 2016 sebagian besar tamat SD sebanyak $61,3 \%$. Jenis pekerjaan pasangan usia subur (PUS) komunitas samin tahun 2016 sebagian besar tani.

2. $98,5 \%$ responden berpengetahuan baik tentang perawatan kehamilan (ante natal care), dan 96,2\% responden berpengetahuan baik tentang perawatan persalinan (post natal care ). Sedangkan 92,3 \% responden berpengetahuan baik tentang keluarga berencana $(\mathrm{KB})$

3. $97,7 \%$ responden bersikap mendukung terhadap pelayanan ante natal care, dan $97,7 \%$ responden bersikap mendukung terhadap pelayanan post natal care Sedangkan $\quad 97,7 \%$ responden bersikap mendukung terhadap pelayanan keluarga berencana.

4. $95,4 \%$ responden melakukan ante natal care, dan 92,3 \% responden juga melakukan perawatan pasca persalinan (post natal care), sedangkan $76,2 \%$ responden melakukan keluarga berencana $(\mathrm{K}$
5. Ada hubungan antara tingkat pengetahuan responden dengan praktik responden terhadap kesehatan reproduksi perawatan ante natal care.

6. Ada hubungan antara tingkat pengetahuan responden .dengan sikap responden terhadap kesehatan reproduksi perawatan post natal care

7. Ada hubungan antara tingkat pengetahuan responden dengan praktik responden terhadap kesehatan reproduksi perawatan post natal care

8. Ada hubungan antara tingkat pengetahuan responden .dengan praktik respondpeen terhadap kesehatan reproduksi ( Keluarga Berencana)

9. Ada hubungan antara tingkat pengetahuan responden dengan praktik responden terhadap kesehatan reproduksi Keluarga Berencana.

10. Variabel yang paling berhubungan pada PUS komunitas Samin terhadap kesehatan reproduksi (Perawatan ante natal care, Perawatan post natal care, Implementasi KB) di Kabupaten Blora.

11. Berkaitan pelayanan kesehatan reproduksi masyarakat Samin sudah memahami akan pentingnya kesehatan reproduksi terutama pada kehamilan, persalinan, dan KB, sehingga perlu peningkatan pelayanan 
tenaga kesehatan. Peranan petugas kesehatan (bidan) dan petugas kesehatan dari Puskesmas tetap melakukan tugasnya dengan baik dan melakukan kunjungan, memberikan penyuluhan dan pengawasan kesehatan reproduksi pada pasangan usia subur (PUS) masyarakat Samin diwilayah kerjanya demi tercapainya kesehatan reproduksi yang baik. Hambatan yang dialami oleh petugas kesehatan dalam memberikan pelayanan kesehatan reproduksi karena masih kuatnya ajaran Saminisme di masyarakat Samin, selain itu budaya masyarakat Samin yang masih meyakini terhadap hal - hal yang bersifat tabu seperti membicarakan tentang sexualitas karena mereka mengganggap hal tersebut adalah "Saru Tomo " yaitu suatu perilaku yang tidak pantas didiskusikan atau dibicarakan tetapi baik atau mulia kalau dilakukan.

\section{Acknowledgement}

Ucapan banyak terimakasih disampaikan kepada semua pihak yang telah membantu terlaksananya kegiatan penelitian oleh tim Peneliti Prodi Keperawatan Blora Politeknik Kesehatan Kemenkes Semarang.

\section{Pustaka}

1. Astrand, P.O \&Rodahl, K. 1989. Textbook of Abdul Bari Saaifuddin. 2003. Buku Panduan Praktis Pelayanan Kontrasepsi, Bina Pustaka, Jakarta.

2. Depkes RI. 2001.Yang Perlu Diketahui Petugas Ksehatan Tentang Kesehatan Reproduksi, Jakarta.

3. De Weerdt,I.1999.Diadetes Edducation, Behavioral, Medical, Organizational and Economic Aspect, A Multi Centre Evaluation Study, Den Haag : Cip, Data Konniklijke Bibliotheek.

4. Depkes RI.2008.Buku Kesehatan Ibu Dan Anak, Jakarta.

5. Fishben,I,and Ajzen.1975. Introduction to Theory and Reseearch, Massachuset, Adison Weshly Publishing Co.

6. Green LW. 2000. Health Promotion Planing An Educational and Enviromental Approacch, Mayfield Publishing Company, London.

7. Helen, F. 2002. Perawatan Maternitas, EGC Jakarta.
8. Kantor Pariwisata Dan Kebudayaan Kab. Blora. 2007. Kearifan Lokal Dilingkungan Masyarakat Samin Kabupaten Blora Jawa Tengah, Kepel Press, Yogyakarta.

9. Lexy J. 2002. Metode Penelitian Kualitatif, Remaja Rosda Karya, Bandung,1996.

10. Arikunto,S, Prosedur Penelitian Suatu Pendekatan Praktik, Rineka Cipta, Jakarta.

11. Notoatmojo,B. Jannah, M, 2004. Metode Penelitian, Rineka Cipta, Jakarta.

12. Notoatmodjo Soekidjo.2003. Pengantar Pendidikan Kesehatan dan Ilmu Perilaku Kesehatan, Rineka Cipta, Yogyakarta.

13. Suripan Sadi Hutomo.1996. Tradisi Dari Blora, Citra Almamater, Semarang.

14. Smet,B. 1994.Theory of Resoned Action, The John Hopkins University, Mayfield Publishing, USA. 